\title{
PENGARUH PROGRAM CSR "KUTA BEACH SEA TURTLE CONSERVATION" TERHADAP BRAND IMAGE PERUSAHAAN
}

\author{
Ratih Hidayati, Hendra Wijayanto \\ Universitas 17 Agustus 1945 Jakarta \\ ratihkurnia20@gmail.com, hendra.pelajar@gmail.com
}

\begin{abstract}
Abstrak. Penelitian ini bertujuan untuk menganalisis pengaruh Corporate Social Responsibility (CSR), terhadap brand image PT Coca Cola Amatil Indonesia Tbk. Jenis penelitian ini adalah penelitian kuantitatif. Populasi dalam penelitian ini adalah masyarakat sekitar konservasi penyu yang mengetahui dan mengikuti program CSR yang dilakukan oleh PT Coca Cola Amatil Indonesia Tbk. Pengambilan sampel berdasarkan metode non probability sampling dengan teknik purposive sampling dengan jumlah sebanyak 99 responden. Analisis data yang digunakan adalah regresi sederhana dan uji hipotesis dengan menggunakan uji $\mathrm{F}$ dan uji t. Hasil penelitian ini menunjukkan bahwa program Corporate Social Responsibility (CSR) memberikan pengaruh yang signifikan sebesar $41,6 \%$ terhadap brand image PT Coca Cola Amatil Indonesia Tbk.
\end{abstract}

\section{Kata Kunci: Corporate Social Responsibility, Brand Image, Kuta Beach Sea Turtle Conservation}

Abstract. This study aims to analyze the influence of corporate social responsibility (CSR), on the brand image of PT Coca Cola Amatil Indonesia Tbk. This type of research is quantitative research. The population in this study is the community around the conservation of turtles who know and follow the CSR program conducted by PT Coca Cola Amatil Indonesia Tbk. Sampling based on non-probability sampling method with purposive sampling technique with the number of 99 respondents. Data analysis used is simple regression and hypothesis test by using $F$ test and $t$ test. The results of this study indicate that the Corporate Social Responsibility (CSR) program has a significant impact 41,6\% on the brand image of PT Coca Cola Amatil Indonesia Tbk.

Keywords: Corporate Social Responsibility, Brand Image, Kuta Beach Sea Turtle Conservation

\section{Pengantar}

Tanggung jawab sosial perusahaan (Corporate Social Responsibility) didefinisikan sebagai proses mengkomunikasikan tindakan sosial dan lingkungan dari organisasi untuk kelompok-kelompok kepentingan tertentu dalam masyarakat dan untuk masyarakat luas. CSR merupakan salah satu program kegiatan yang dilakukan perusahaan untuk menunjukan kepedulian kepada masyarakat. Hal ini bukan merupakan kewajiban perusahaan melainkan sukarela pihak perusahaan. Namun beberapa tahun belakangan, CSR menjadi prioritas perusahaan dan menjadi agenda wajib yang dilakukan perusahaan.

Bersamaan dengan meningkatnya jumlah perusahaan yang melaporkan kegiatan sosial dan lingkungan mereka kepada publik, keragaman jenis laporan CSR yang dikeluarkan menjadi perhatian. Selain itu, laporan kegiatan sosial dan lingkungan yang semakin disertai dengan pernyataan jaminan pihak, sering dukungan 
sudah dimasukkan dengan bahan tambahan pada website perusahaan. Perusahaan penanaman modal berkewajiban memprogramkan kegiatas CSR sehingga dapat meningkatkan jaminan kelangsungan aktivitas perusahaan karena adanya hubungan yang serasi dan saling ketergantungan antara pengusaha dan masyarakat. Program perusahaan melalui CSR diharapkan membantu brand image perusahaan tersebut untuk dikenal oleh khalayak luas.

Program Kuta Beach Sea Turtle Conversation yang dijalankan PT Coca-Cola Amatil Indonesia TBK sejak tahun 2010 telah berhasil meningkatkan kebersihan wilayah pesisir Bali. Selain menjaga kebersihan pantai, program ini juga berkontribusi positif dalam memberikan kesempatan hidup yang lebih besar bagi satwa lokal Bali. Berdasarkan data yang tercatat dari Pro Fauna dan tokoh masyarakat, dari sejak kami mendirikan BBCU Program lebih banyak telur penyu laut menetas di pantai. Inilah yang memicu CCAI untuk mengembangkan fasilitas konservasi di pantai Kuta yang kemudian dikenal sebagai

Kuta Beach Sea Turtle Conservation (KBSTC) dibangun pada tahun 2010 untuk meningkatkan kepedulian masyarakat dan turis di pantai Bali tentang pentingnya perlindungan terhadap satwa lokal. CCAI mendukung upaya yang dilakukan oleh Pro-Fauna, organisasi nirlaba yang bekerja untuk melindungi satwa-satwa liar di Indonesia, dan Desa Adat Kuta dalam mempertahankan program yang mereka jalani untuk melindungi penyu dan membantu para penyu tersebut kembali ke habitat alaminya.

Dari uraian latar belakang penelitian yang telah dibahas sebelumnya, maka tujuan penelitian adalah menganalisi pengaruh program Corporate Social Responsibility "Kuta Beach Sea Turtle Conservation" terhadap brand image PT. Coca Cola Amatil Indonesia Tbk".

\section{Kajian Teoritis}

\section{Corporate Social Responsibilty}

Berdasarkan konsep Triple Bottom Line, Corporate Social Responsibility dan dipopulerkan oleh Jhon Elkington pada tahun 1998 pada bukunya "Canibal With Forks, The Triple Bottom Line of Twentieth Century Business". Elkington mendeksripsikan Triple Bottom Line pada istilah economic prosperity, environmental quality, dan social justice. Selain mengejar profit perusahaan juga memperhatikan dan terlibat dalam pemenuhan kebutuhan masyarakat (people) dan turut berkontribusi aktif dalam menjaga kelestarian lingkungan (planet). Konsep Triple Bottom Line digunakan sebagai landasan dan aplikasi program Corporate Social Responsibility pada sebuah perusahaan. Tiga kepentingan yang menjadi satu ini merupakan garis besar haluan dan tujuan utama tanggung jawab social pada perusahaan.

Menurut Lawrence, Weber and Post, 2005 dalam buku nya Kartini, (2013;2) Corporate Social Responsibility adalah"CSR means that a corporation should be held accountable for any of its actions that affect people, their communicties, and their environment". Definisi CSR lainnya menurut World Business Council for Sustainable Development (1999) adalah "The continuing commitment by business to behave ethically and contribute to economic development while improving the quality of life of the workforce and their families as well as of the local community and society at large". 
Dari beberapa definisi Corporate Social Responsibility menurut para ahli dapat disimpulkan bahwa merupakan suatu konsep bahwa organisasi, khususnya perusahaan, memiliki berbagai bentuk tanggung jawab terhadap seluruh pemangku kepentingannya, yang di antaranya adalah konsumen, karyawan, pemegang saham, investor dan lingkungan dalam segala aspek operasional perusahaan yang mencakup aspek ekonomi, sosial, dan lingkungan. Oleh karena itu, CSR berhubungan erat dengan "pembangunan berkelanjutan", di mana suatu organisasi, terutama perusahaan, dalam melaksanakan aktivitasnya harus mendasarkan keputusannya tidak semata berdasarkan dampaknya dalam aspek ekonomi, misalnya tingkat keuntungan atau dividen, melainkan juga harus menimbang dampak sosial dan lingkungan yang timbul dari keputusannya itu, baik untuk jangka pendek maupun untuk jangka yang lebih panjang. Dengan pengertian tersebut, CSR dapat dikatakan sebagai kontribusi perusahaan terhadap tujuan pembangunan berkelanjutan dengan cara manajemen dampak (minimisasi dampak negatif dan maksimisasi dampak positif) terhadap seluruh pemangku kepentingannya.

Kotler dan Lee (2005) menyebutkan enam jenis aktivitas program CSR. Promosi Kegiatan Sosial (Cause Promotions) merupakan jenis aktivitas pertama yang dapat dilakukan oleh perusahaan. Dalam hal ini, perusahaan menyediakan dana atau sumber daya lainnya yang dimilki perusahaan untuk meningkatkan kesadaran masyarakat terhadap suatu kegiatan social atau untuk mendukung pengumpulan dana, partisipasi dari masyrakat atau prekrutan tenaga sukarela untuk suatu kegiatan tertentu.

Jenis aktivitas yang kedua dari CSR yakni Pemasaran Terkait Kegiatan Sosial (Cause Related Marketing). Perusahaan memiliki komitmen untuk menyumbangkan persentase tertentu dari penghasilannya untuk suatu kegiatan social berdasarkan besarnya penjualan produk.

Jenis aktivitas selanjutnya ialah Pemasaran Kemasyarakatan Korporat (Corporate Social Marketing). Perusahaan mengembangkan dan melaksanakan kampanye untuk mengubah perilaku masyarakat dengan tujuan meningkatkan kesehatan dan keselamatan pubik, menjaga kelestarian lingkuangan hidup serta meningkatkan kesejahteraan masyarakat.

Jenis aktivitas keempat yakni Kegiatan Filantropi Perusahaan (Corporate Philanthropy). Perusahaan ini memberikan sumbangan langsung dalam bentuk derma untuk kalangan masyarakat tertentu.

Jenis aktivitas CSR ke lima ialah Pekerja Sosial Kemasyarakatan Secara Sukarela (Community Volunteering). Perusahaan mendukung serta mendorong para karyawan, rekan peagang eceran atau para pemegang franchise agar menyisihkan waktu secara sukarela guna membantu organisasi masyarakat lokal maupun masyarakat yang menadi sasaran program.

Jenis aktivitas CSR yang ke enam atau terakhir ialah Praktika Bisnis yang Memiliki Tanggung Jawab Sosial (Socially Responsible Business Practise). Perusahaan melaksanakan aktivitas bisnis melampaui aktivitas bisnis yang diwajibkan oleh hokum serta melaksanakan investasi yang mendukung kegiatan sosial dengan tujuan meningkatkan kesejahteraan komunitas dan memelihara lingkungan hidup. 
Kartini (2013:54) menyebutkan delapan indikator yang digunakan dalam mengukur implementasi CSR, yakni: (1) Leadership (Kepemimpinan). Program CSR dapat dikatakan berhasil jika mendapatkan dukungan dari top management perusahaan. Terdapat kesadaran filantropik dari pimpinan yang menjadi dasar pelaksanaan program. (2) Proporsi Bantuan. CSR dirancang bukan semata-mata pada kisaran anggaran saja, melainkan pada tingkatan serapan maksimal, jadi apabila areanya luas, maka anggarannya harus lebih besar. Jadi tidak dapat dijadikan tolak ukur apabila anggaran besar pasti menghasilkan program yang bagus. (3) Transparansi dan Akuntabilitas. Terdapat laporan tahunan (annual report), dan mempunyai mekanisme audit sosial dan finansial dimana audit sosial terkait dengan pengujian sejauh mana program-program CSR telah dapat ditujukan secara benar sesuai kebutuhan masyarakat, perusahaan mendapatkan umpan balik dari masyarakat secara benar dengan melakukan interview dengan para penerima manfaat. (4) Cakupan Wilayah (Coverage Area. Terdapat identifikasi penerima manfaat secara tertib dan rasional berdasarkan skala prioritas yang telah ditentukan. (5) Perencanaan dan Mekanisme Monitoring dan Evaluasi. Dalam perencanaan perlu ada jaminan untuk melibatkan multi stakeholder pada setiap siklus pelayanan proyek. Terdapat kesadaran untuk memperhatikan aspek-aspek lokalitas (local wisdom), pada saat perencanaan ada kontribusi, pemahamam dan penerimaan terhadap budaya-budaya lokal yang ada. Terdapat blue-print policy yang menjadi dasar pelaksanaan program. (6) Pelibatan Stakeholder (Stakeholders Enggagement). Terdapat mekanisme koordinasi regular dengan stakeholders, utamanya masyarakat. Terdapat mekanisme yang menjamin partisipasi masyarakat untuk dapat terlibat dalam siklus proyek. (7) Keberlanjutan (Sustainability). Terjadi alih peran dari korporat ke masyarakat. Tumbuhnya rasa memiliki (sense of belonging) program dan hasil program pada diri masyarakat, sehingga masyarakat dapat ikut andil dalam menjaga dan memelihara program dengan baik. Adanya pilihan partner program yang bisa menjamin bahwa tanpa keikutsertaan perusahaan, program bisa tetap dijalankan sampai selesai dengan partner tersebut. (8) Hasil nyata (Outcome). Terdapat dokumentasi hasil yang menunjukkan berkurangnya angka kesakitan dan kematian (dalam bidang kesehatan) atau berkurangnya angka buta huruf dan meningkatnya kemampuan SDM (dalam bidang pendidikan) atau parameter lainnya sesuai dengan bidang CSR yang dipilih oleh perusahaan. Terjadinya perubahan pola pikir masyarakat. Memberikan dampak ekonomi masyarakat yang dinamis. Terjadinya penguatan komunitas (community empowerment).

\section{Brand Image}

Brand Image menurut Supranto dan Limakrisna (2007: 132), didefinisikan sebagai apa yang konsumen pikir dan rasakan ketika mendengar atau melihat suatu merek dan apa yang konsumen pelajari tentang merek tersebut. Brand image disebut juga sebagai memori merek yang skematis, berisi interprestasi pasar sasaran tentang

karakteristik produk, manfaat produk, situasi penggunaan dan karakteristik pemasaran.

Menurut Simamora (2003: 124), brand image biasanya menyangkut tentang citra produk, perusahaan, partai, orang, atau apa saja yang terbentuk dalam benak seseorang. Citra adalah konsep yang mudah dimengerti tetapi sulit untuk dijelaskan secara sistematis karena sifatnya abstrak. 
Dari penjelasan kedua definisi brand image menurut para ahli, dapat disimpulkan brand image adalah gambaran atau kesan yang terbentuk di benak konsumen ketika mendengar atau melihat suatu merek, produk, perusahaan atau apapun itu yang timbul di benak konsumen, dimana brand ini berisi tentang interprestasi pasar, manfaat produk, situasi penggunaan dan karakteristik pemasaran.

Keller (1998: 94) Brand image dibagi menjadi empat dimensi, yaitu; asosiasi merek (types of brand association), kesukaan pada merek (favorability of brand association), kekuatan merek (strength of brand association) dan keunikan merek (uniqueness of brand association).

Dimensi pertama yakni Brand association. Dalam hal ini yang tertanam secara positif di benak konsumen dapat mempengaruhi tingkat kepercayaan konsumen terhadap merek tersebut. Oleh karena itu penting untuk selalu mempertahankan brand association yang positif pada suatu produk sehingga konsumen akan memiliki tingkat kepercayaan yang tinggi.

Keller (1998: 94) membagi dimensi brand association menjadi tiga, yaitu: (1) Attributes, yakni kelengkapan yang memberikan karakteristik pada suatu produk yang dapat mempengaruhi pemikiran konsumen tentang produk tersebut. (2) Benefits, yakni nilai personal suatu produk yang membuat konsumen menjadi terikat dengan suatu produk karena mampu memenuhi kebutuhan konsumen. (3) Attitudes, yakni hasil evaluasi konsumen secara keseluruan mengenai suatu brand. Brand attitudes penting untuk selalu dijaga karena akan mempengaruhi perilaku konsumen terhadap suatu brand. Brand attitudes ini tergantung dari kelengkapan atribut suatu brand.

Dimensi kedua yaitu Favorability Brand Assosiation. Dimensi ini merupakan tingkat kesukaan konsumen terhadap suatu brand sangat penting untuk selalu dipertahankan. Dengan konsumen menyukai suatu brand, maka tingkat kepercayaan konsumen terhadap brand tersebut juga akan semakin tinggi.

Keller (1998: 106) dibagi ke dalam dua kategori, yaitu: (1) Desirability of the brand yakni seberapa penting atau seberapa bernilainya citra suatu brand yang terbentuk di benak konsumen. Hal ini berguna untuk mengetahui tingkat kebutuhan konsumen sesuai yang dijelaskan dengan menggunakan teori Maslow's hierarchy, yaitu; physiological needs (food, water, air, shelter and sex), safety and security needs (protection, order and stability), social needs (affection, friendship and belonging), ego needs (prestige, status dan self - respect) dan self-actualization (self - fulfillment). (2) Deliverability of the brand yakni keunggulan yang dimiliki suatu produk untuk memenuhi kebutuhan konsumen pada periode waktu jangka panjang.

Dimensi selanjutnya ialah dimensi Strength Brand Assosiation Informasi mengenai suatu perusahaan, produk dan brand yang dikeluarkan oleh perusahaan penting untuk diketahui oleh konsumen. Semakin dalam informasi yang diketahui oleh konsumen, akan mempengaruhi tingkat kepercayaan konsumen terhadap produk yang dikeluarkan suatu brand. Keller (1998: 104 - 105) membagi strength brand association menjadi dua dimensi, yaitu: (1) Quality and Quantity of Processing yakni semakin dalam perhatian yang diberikan konsumen terhadap suatu brand, maka semakin mudah dan kuat informasi yang disampaikan untuk dipahami oleh konsumen. (2) Recall of Brand Association yakni pemberian atau penyampaian informasi yang dilakukan secara berkala untuk memastikan informasi yang diberikan kepada 
konsumen dapat dipahami dengan baik, sehingga terjadi kesesuaian makna yang ingin disampaikan suatu brand kepada konsumen.

Dimensi keempat ialah Uniqueness brand association. Dimensi ini penting untuk selalu diciptakan oleh perusahaan. Jika suatu brand memiliki keunikan yang tidak dimiliki brand lain, maka brand ini memiliki nilai tambah di mata konsumen. Keller (1998: 108) menjabarkan dimensi uniqueness brand association sebagai berikut: (1) Favorably evaluated association yakni keunikan yang dimiliki oleh suatu brand merupakan salah satu faktor penting kesuksesan suatu brand dapat dibedakan oleh konsumen. (2) Research on noncomparable alternatives yakni meskipun suatu brand berbeda jenis produk dengan brand lainnya, namun antara kedua brand ini tetap dapat dikatakan saling bersaing secara tidak langsung karena setiap brand memiliki nilai asosiasi yang saling menggungulkan antara satu dengan yang lain.

\section{Metodologi}

Berdasarkan latar belakang dan kajian teoretis, penelitian ini menggunakan metode kuantitatif eksplanatif, karena definisi kuantitatif eksplanatif sesuai dengan penelitian si peneliti, yaitu digunakan untuk mengetahui pengaruh hubungn sebab - akibat antara dua variabel atau lebih yang terdiri dari variabel bebas dan variabel terikat, dalam hal ini adalah untuk mengetahui seberapa besar brand image mempengaruhi brand trust perusahaan. Selain itu, data yang didapat dalam penelitian kuantitatif eksplanatif adalah hasil kuesioner yang disebar peneliti kepada narasumber yang ditentukan peneliti kemudian dikombinasikan dengan data statistik berupa data numerik yang akan dihitung menggunakan SPSS untuk membuktikan berapa persen variabel bebas mempengaruhi variabel terikat.

Pada penelitian ini, peneliti ingin meneliti dengan populasi masyarakat sekitar Kuta Beach Sea Turtle Conservation sebanyak 7000 masyarakat. Dengan menghitung sampel menggunakan model Isacc dan Michael dengan tingkat kesalahan 10\%, maka sampel yang digunakan untuk penelitian ini berjumalh 99 responden. 99 responden ini nantinya adalah masyarakat yang mengikuti proses pelepasan tukik di Kuta Beach Bali.

\section{Diskusi}

\section{Uji Validitas}

Uji Validitas Variabel X dan Variabel Y

Dari hasil perhitungan tabel, diperoleh hasil validitas secara keseluruhan variabel $\mathrm{X}$ adalah valid, karena nilai $\mathrm{r}$ hitung $>\mathrm{r}$ tabel, yaitu nilai $\mathrm{r}$ hitung $>\mathrm{r}$ tabel yang digunakan adalah $(\mathbf{0 , 1 6 6 3 )}$. 


\section{Uji Reliabilitas}

Uji Reliabilitas Variabel X dan $Y$

Tabel 1. Reliability Statistics

\begin{tabular}{|c|c|c|c|}
\hline Variable & Cronbach's Alpha & $\begin{array}{l}\text { Cronbach's Alpha } \\
\text { Based on } \\
\text { Standardized Items }\end{array}$ & $\mathrm{N}$ of Items \\
\hline$x$ & .853 & .851 & 18 \\
\hline $\mathrm{Y}$ & .703 & .706 & 12 \\
\hline
\end{tabular}

(Sumber : SPSS, 2018)

Dari tabel 1 diketahui nilai Alpha Cronbach variabel X adalah 0,835 dengan dengan jumlah item sebanyak 18, maka dapat disimpulkan bahwa variabel $\mathrm{X}$ adalah reliabel. Pernyataan dinilai reliabel apabila pernyataan diuji kembali pada responden lain mendapatkan jawaban yang sama.

Dari tabel 1 diketahui nilai Alpha Cronbach variabel Y adalah 0,710 dengan dengan jumlah item sebanyak 12, maka dapat disimpulkan bahwa variabel $Y$ adalah reliabel. Pernyataan dinilai reliabel apabila pernyataan diuji kembali pada responden lain mendapatkan jawaban yang sama.

\section{Uji Hipotesis}

Uji Hipotesis Ha Corporate Social Responsibility (X) Terhadap Brand Image (Y)

Uji Hipotesis Ha secara regresi linier sederhana (Uji $t$ ). Berikut hasil perhitungan SPSS 16 uji signifikan variabel Brand Image $(X)$ terhadap Brand Image $(\mathrm{Y})$.

\section{Tabel 2. Hasil Uji T Hipotesis Ha Brand Image $(X)$}

\section{Terhadap Brand Trust (Y)}

\section{Coefficients ${ }^{a}$}

\begin{tabular}{|rr|r|r|r|r|r|}
\hline \multirow{2}{*}{ Model } & \multicolumn{2}{|c|}{$\begin{array}{c}\text { Unstandardized } \\
\text { Coefficients }\end{array}$} & $\begin{array}{c}\text { Standardized } \\
\text { Coefficients }\end{array}$ & & \\
\cline { 2 - 5 } & \multicolumn{1}{|c|}{$\mathrm{B}$} & Std. Error & \multicolumn{1}{c|}{ Beta } & \multicolumn{1}{c|}{$\mathrm{t}$} & \multicolumn{1}{c|}{ Sig. } \\
\hline 1 & (Constant) & 21.431 & 3.662 & & 5.852 & .000 \\
& CSR $(X)$ & .387 & .046 & .645 & 8.315 & .000 \\
\hline
\end{tabular}

a. Dependent Variable: Brand Image (Y)

(Sumber : SPSS, 2018)

Nilai $\mathrm{t}$ hitung pada variabel Brand Image $(X)$ adalah sebesar 8,315 dengan tingkat signifikansi 0,000. Karena 8,315 >1,29034 dan 0,000<0,1 maka Ha diterima dan Ho ditolak. Dapat disimpulkan bahwa variabel Brand Image $(X)$ berpengaruh positif dan signifikan terhadap Brand Image (Y). 


\section{Uji Korelasi}

Tabel 3. Uji Korelasi

\begin{tabular}{|c|c|c|c|}
\hline & & $\operatorname{CSR}(X)$ & $\begin{array}{l}\text { Brand Image } \\
\text { (Y) }\end{array}$ \\
\hline \multirow[t]{3}{*}{$\operatorname{CSR}(X)$} & $\begin{array}{l}\text { Pearson } \\
\text { Correlation }\end{array}$ & 1 & $.645^{* *}$ \\
\hline & Sig. (2-tailed) & & .000 \\
\hline & $\mathrm{N}$ & 99 & 99 \\
\hline \multirow[t]{3}{*}{$\begin{array}{l}\text { Brand Image } \\
(\mathrm{Y})\end{array}$} & $\begin{array}{l}\text { Pearson } \\
\text { Correlation }\end{array}$ & $.645^{* *}$ & 1 \\
\hline & Sig. (2-tailed) & .000 & \\
\hline & $\mathrm{N}$ & 99 & 99 \\
\hline
\end{tabular}

**. Correlation is significant at the 0.01 level (2-tailed).

(Sumber : SPSS, 2018)

Dari hasil data tabel 3 dapat dilihat bahwa nilai kolerasinya adalah kuat yakni Corporate Social Responsibility $(\mathrm{X})$ terhadap Brand Image $(\mathrm{Y})$ sebesar $(0,645)$ sesuai dengan pedoman interpretasi hubungan pengaruh menurut Sugiyono (2014: 183)

\section{Koefisien Determinasi (R2)}

Koefisien determinasi bertujuan untuk mengukur seberapa jauh kemampuan model dalam menerangkan variasi variabel dependen. Nilai koefisien determinasi adalah $0<\mathrm{R}^{2}<1$. Koefisien determinasi yang mendekati satu berarti variabel-variabel independen memberikan hampir semua informasi yang dibutuhkan untuk memprediksi variabel dependen.

\section{Tabel 4. Koefisien Determinasi (R2) Model Summary}

\begin{tabular}{|l|r|r|r|r|}
\hline Model & \multicolumn{1}{|c|}{$\mathrm{R}$} & R Square & $\begin{array}{c}\text { Adjusted R } \\
\text { Square }\end{array}$ & $\begin{array}{l}\text { Std. Error of } \\
\text { the Estimate }\end{array}$ \\
\hline 1 & $.645^{\mathrm{a}}$ & .416 & .410 & 3.020 \\
\hline
\end{tabular}

a. Predictors: (Constant), CSR $(X)$

(Sumber : SPSS, 2018)

Berdasarkan tabel 4 terlihat tampilan output SPSS model summary besarnya Adjusted $R$ Square Corporate Social Responsibility (X) adalah 0,416, hal ini berarti 41,6\% variabel Brand Image (Y) dipengaruhi oleh Corporate Social Responsibility (X). Sedangkan sisanya 59,4\% (100\%-41,6\%) disebabkan hal lain di luar variabel tersebut. Sehingga untuk meningkatkan Brand Image tidak hanya berdasarkan program Corporate Social Responsibility saja, namun juga diperlukan faktor-faktor pendukung lainya seperti kegiatan Integrated Marketing Communication atau program lainnya. 


\section{Kesimpulan}

Peneliti menarik kesimpulan dari analisa dan pembahasan, hasil analisis hipotesis atau uji $\mathrm{t}$ adalah, nilai $\mathrm{t}$ hitung pada variabel Corporate Social Responsibility $(\mathrm{X})$ adalah sebesar 7,680 > 1,29053 dan 0,000 < 0,1 maka Ha diterima dan Ho ditolak. Dapat disimpulkan bahwa variabel Corporate Social Responsibility $(\mathrm{X})$ berpengaruh positif dan signifikan terhadap Brand Image (Y). Begitu pula dengan hasil koefisien determinasi R2 Corporate Social Responsibility (X) adalah 0,416, hal ini berarti 41,6\% variabel Brand Image (Y) dipengaruhi oleh Corporate Social Responsibility (X). Sedangkan sisanya 59,4\% disebabkan hal lain di luar variabel tersebut.

\section{Referensi}

Hadi, Nor. (2011). Corporate Social Responsibility. Yogyakarta: Graha Ilmu.

Imam, Ghozali. (2009). Aplikasi Multivariat Dengan Program SPSS. Semarang : Badan Penerbit Universitas Diponegoro.

Kartini, Dwi. (2009). Corporate Social Responsibility: Transformasi konsep sustainability management dan implementasinya di Indonesia, Bandung: PT. Refika Aditama

Keller, Kevin Lane. (1998). Strategic Brand Management Building Measuring and Managing Brand Equity. Jakarta : PT. Gramedia Pustaka Utama.

Kotler, Philip and Nancy, lee. (2005). Corporate Social Responsibility. Doing The Most good for Your Company and Your Cause. New Jersey: Jan Wiley \& Sons, Inc

Kotler, Philip and Nancy Lee. (2005). Corporate Social Responsibility Doing the Most Good for Your Company and Your Cause. New Jersey; John Willey \& Sons.

Prasetyo, Bambang. Jannah, lina Miftahul. (2005). Metode Penelitian Kuantitatif Teori dan Aplikasi. Jakarta: Rajawali Press

Sarwono, Jonathan. (2006). Metode Penelitian Kuantitatif dan Kualitatif. Yogyakarta : Graha Ilmu.

Sugiarti. (2015). Pengaruh Persepsi Tentang Corporate Social Responsibility Terhadap Reputasi Perusahaan Yang Dimediasi Oleh Citra Merek. Universitas Udayana Bali: Skripsi Tidak Diterbitkan

Sugiyono. (2014). Metode Penelitian Kuantitatif Kualitatif dan RED. Bandung : Alfabeta.

Suharsimi, Arikunto. (2010). Prosedur Penelitian Suatu Pendekatan Praktik. Jakarta : PT. Rhineka Cipta.

World Summit on Sustainable Development (WSSD). (2002). Earth Observation for Sustainable Development, Bali, Indonesia. 